\title{
A Glance at Mosses
}

\author{
HENRY S. CONARD, Sc.D.
}

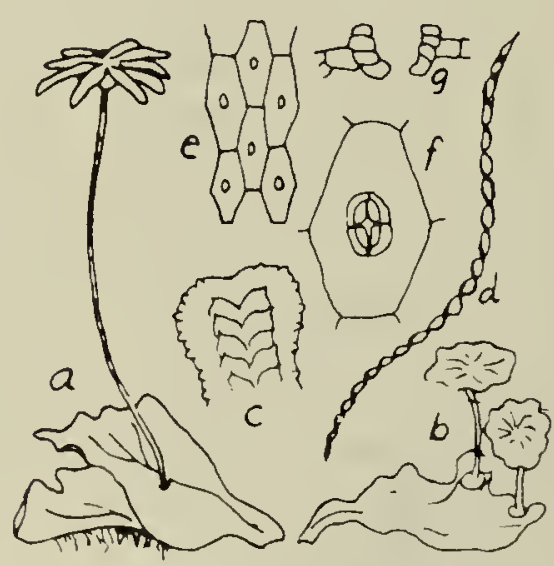

\begin{abstract}
Marchontio polymorpho L. $O$, female plont; $b$, mole plant; $c$, scoles on under side of thallus; $d$, elater; e, surface of thollus; $f$, pore; g, section of pore. All over N. America and Europe, on freshly disturbed cloyey or silty soil, especially on burned places. Spores yellow. The umbrello-like femole receptacles grow to full size even if not one egg is fertilized. The golden yellow sporophytes are found under the umbrellos in late june in lowo. Two other species occur in the South.
\end{abstract}

FIGURE 1. Marchantia. From "How to know the Mosses," by permission of the Editor.

Mother Nature makes her little ornaments with more exquisite care than she devotes to larger things. A mountain is majestic in its massive irregular outlines. A moss is miraculous for the elegant exactness of its finest microscopic structure. We can recognize a bur oak by a leaf or an acorn with the naked eye. We can name a moss with the aid of a hand lens $(15 \mathrm{x})$. We find precision in the details of moss structure, the more so the farther we go with the compound microscope.

As examples of the mosses of Saskatchewan we may choose the common liverwort of all the botany texts, Marchantia, and the Woodsy Mnium, Mnium cuspidatum, a leafy moss.

Marchantia grows flat on the ground in moist places, often covering several square feet. I have it from Pike Lake, near Saskatoon. It lies in green, forking strips two to four inches long and half an inch wide, with a faint midrib. It is fastened to the ground by innumerable fine colorless hairs. The surface is marked off into tiny diamondshaped areas, scarcely visible to the naked eye, and in each area is an oval opening by which air gets into the digestive system of the plant. (If the areas are easily visible your plant is Conocephalum. Crush it and discover its aromatic odor).

Marchantia propagates abundantly by means of little disc-shaped "gemmae," produced in tiny fringed cups on the surface of the plant. No other moss does this. Also at times the plants produce umbrella-shaped shoots, a half inch to two inches tall. On some plants the umbrella is merely scalloped around the edge. These umbrellas produce male germ cells. Other plants have umbrellas with long, finger-like lobes. These produce the female germ cells or eggs. When all goes well, little sacs develop on the under side of the female umbrella, which ultimately burst and discharge a golden dust. Not mere dust, however. There are countless little spheres, "spores", each capable of growing into a new green ribbon, and equally countless slender threads, each one pointed at both ends and elegantly wrapped along its length with two yellow spiral bands.

My Woodsy Mniums came from Saskatoon and Nesslin Lake. It is widespread in temperate $\mathrm{North}$ America, Europe and Asia. Usually 


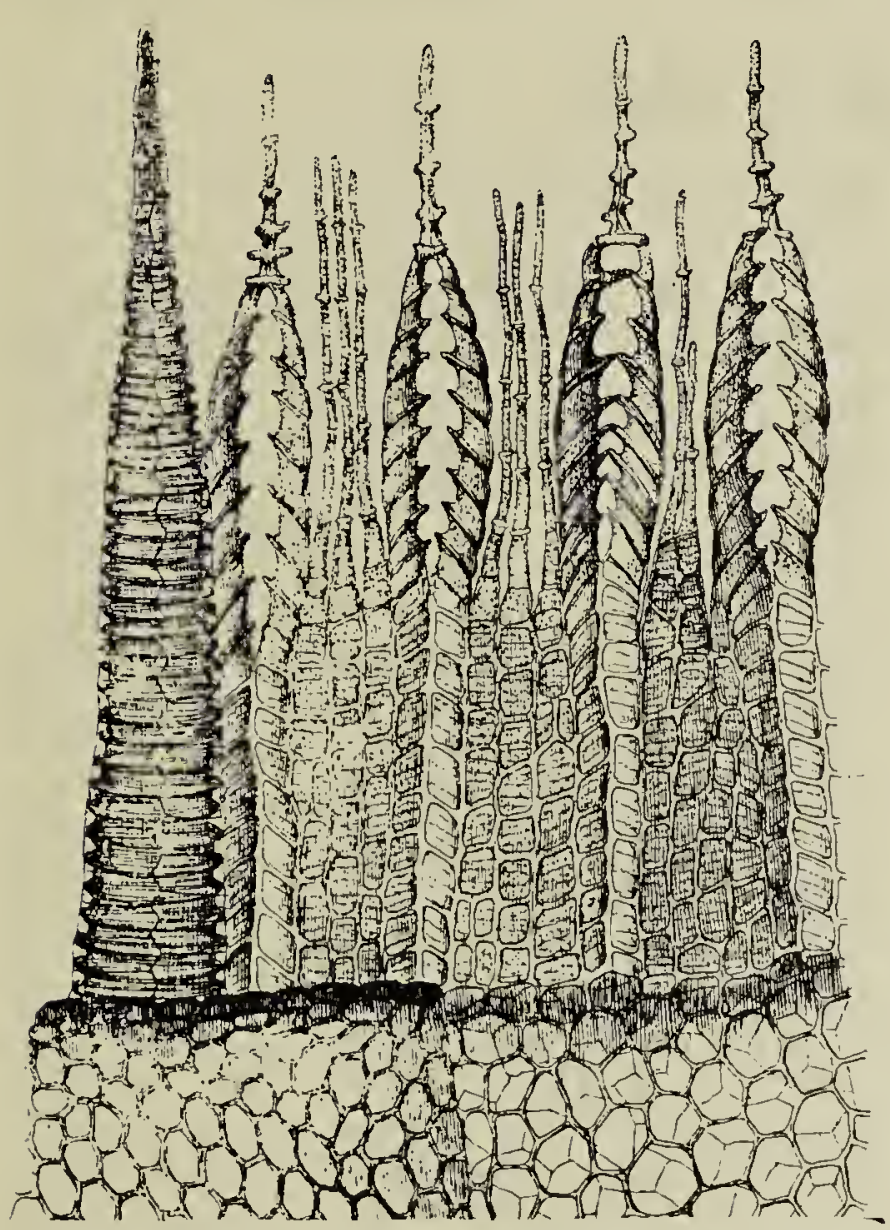

Figure 3. Portion of peristome of Mnium cuspidatum. One outer tooth on the left, the rest the inner membrane. From an old classic: Schimper's Recherches.

it spreads by leafy runners, making extensive sods. The leaves appear to be in two rows, one on each side of the stem. A good hand lens will show a distinct midrib, and fine teeth along the upper (distal) half of the margin of the leaf.

On occasion erect shoots are sent up, half an inch to an inch tall, bearing male and female germ cells in clustered organs a mong the crowded leaves. This occurs in June in Iowa. From such a tuft grows up a slender stalk an inch tall, and on this hangs a cylindrical or barrelshaped "capsule." (If the capsule is pear-shaped it is not a Mnium). In May, that is, after eleven months, a round lid falls from the capsule, disclosing two sets of guards such as no human mind could invent! First there is a circle of sixteen yellowish wedge-shaped teeth with cross bars on the inner side of each tooth. Inside of these there is a rich-browncolored membrane (the color of strong coffee without cream). This membrane is variously but characteristically perforated, and the outer (upper) half of it is divided into sixteen perforated lobes alternating in position with the sixteen outer teeth. Between the lobes one to three fine nodulose threads arise. This whole apparatus around the mouth of the capsule is the "double peristome." Every kind of moss has its own peculiar peristome - or none at all!

O yes, the serious business of the capsule is to produce spores, microscopic cells, each of which can start a new colony of mosses.

As yet we know very little about what mosses live in Saskatchewan, or where they grow. We have about thirty species now. They will be found mostly or only where trees grow, or in marshy places. We need a collector in each voting district, and many expeditions into the far north. Who will do it?

Grinnell College, Grinnell, Iowa, and State University of Iowa.

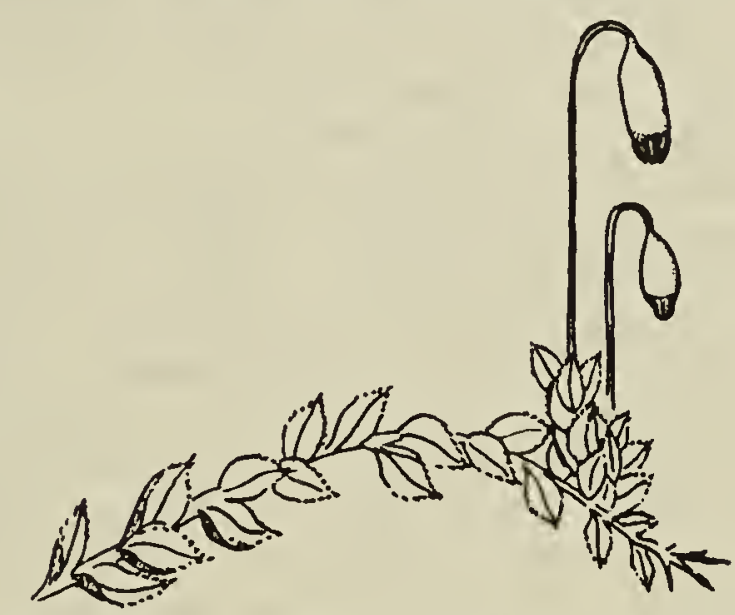

Figure 2. Mnium Cuspidatum. From "Mosses of the Okoboji Region." University of Iowa Publ.

\section{3th ANNUAL SASK. CHRISTMAS BIRD COUNT}

The National Audubon Society's 55 th annual winter bird count will be made during the week after Christmas. The results will then be published in Audubon Field Notes. This is the thirteenth time that the Christmas Count (Dec. 20 to Jan. 3) has been made in Saskatchewan. We hope that even more Society members than usual will participate this year. It will be a great help if observers in one locality can arrange to make their counts on the same day and submit only one report.

For some years now, Dr. Stuart Houston, of Yorkton, has prepared and tabulated the results of the count. This has meant many hours of concentration and hard work. Please assist him by sending in reports not later than the first week in Jan'uary. 